\title{
Exploring Challenges of Municipal Service Delivery in South Africa (1994 - 2013)
}

KANYANE, Modimowabarwa

\section{Abstract}

This his article aims to explore municipal service delivery challenges in South Africa between 1994 and 2013 in order to stimulate debate in addressing problems and challenges confronting municipalities. A fundamental question to be asked stems from the challenges of municipal service delivery. Why, in spite of the existence of regulatory and institutional frameworks, are municipalities still struggling to satisfy basic community needs such as water and electricity amongst others? All of government's official documents and contemporary literature reviewed, including the summative record of historical facts and narrative data, are evidence of the qualitative research design employed in this study. It is clearly articulated in this article that the existence of a local municipality with poor service delivery is, amongst others, a direct consequence or manifestation of municipal capacity constraints, financial viability problems, service delivery protests, convoluted political process, corruption and poor planning as well as monitoring and evaluation challenges. In the main, the article accounts for why service delivery has failed to meet the expectations of the communities and thereby provide some possible propositions for consideration to attempt to bring a resolve to critical issues raised.

Keywords: Municipalities, Service Delivery, Protests, Corruption, Monitoring and Evaluation, South Africa 
Exploring Challenges of Municipal Service Delivery in South Africa (1994 - 2013) 91

\section{Introduction}

Although society aspires to changing the environment to make it a better place to live in, municipalities are increasingly under pressure to respond to basic needs with limited budgets and technical capacity. Sangweni (2003:1) states that the South African public administration introduced reforms to improve performance and municipal service delivery in shaking off the shackles of apartheid. The need to improve performance was underpinned by the state's acceptance of a challenge that municipal service delivery and access to decent municipal services were no longer privileges to be enjoyed by a few. It is the rightful and constitutional expectation of all the people, especially those who were previously exploited, marginalised and disadvantaged.

South Africa underwent transformation to reverse the intentions of apartheid. Between 1994 and 2004, the two terms of democratic government, the state machinery was mainly involved in developing the legislation that would bring about this transformation. The legal and policy processes translated into many pieces of legislation and policies such as acts of parliament, proclamations, white papers and by-laws. However, concerned stakeholders, especially from the civil society movement, felt that despite this legislative development, the results were unsatisfactory. Why, in spite of the existence of a sound regulatory framework which includes, among others, the Local Government Municipal Demarcation Act, 1998 (Act No. 27 of 1998), Local Government: Municipal Structures Amendment Act, 2003 (Act No. 1 of 2003), Local Government: Municipal Systems Amendment Act, 2011 (Act No 7 of 2011), Local Government: Municipal Finance Management (MFMA) Act, 2003 (Act No. 56 of 2003) and Local Government: Municipal Property Rates Amendment Act, 2009 (Act No 19 of 2009) are municipalities still failing to satisfactorily address community needs (Du Plessis 2009, 5)?

In this article, the historical facts about municipalities are presented to provide a clear and compelling case to account for why service delivery has failed to meet the expectations of the communities. The facts are clarified by conceptual and contextual issues that are discussed later in the corpus of this article. Issues regarding the technical resource capacity of the municipalities are raised as part of this exploration and are argued as preludes to the discussion of the reasons and consequences which explain the challenges faced by local municipalities. This article raises critical issues for consideration 
and does not at the end ignore the need to provide possible remedies in addressing the challenges explored before the conclusion is made.

\section{Municipal evolution}

It is an historical fact that the African National Congress (ANC)-led government took over from the apartheid government in 1994. Habib, in Maserumule (2010:18), observes that when the ANC came into power in 1994, it inherited a nearly bankrupt state. Therefore, the government was onerously overwhelmed by reviews of legislation to respond to community needs and this was a challenge in the first five-year term of democratic political leadership (1994-1999) under former President Nelson Mandela. This was followed by another transformation and implementation challenge in the second term, from 1999 to 2004, under the presidency of Thabo Mbeki. The latter epoch overlapped with the constitutional development of the local sphere of government which came into practical existence five years later, after the establishment of national and provincial governments.

While one could say that the sphere of local government was ushered in the right time to assume its well-defined responsibilities, Kanyane (2010:84-85) posits that, on the contrary, transformation and policy development of the national and provincial spheres of government overtook local government. Powell (2012:12) later claims that by the time the implementation began in 2000, the force of this transformative vision was already spent; it was overtaken by hard political and economic realities, overwhelmed by the scale of institutional changes involved and the distance between the ideal and delivering practical change. Kanyane (2010:84-85) writes that it certainly could be argued that the policy development process is very critical and that if local government could have jointly participated in this process from the beginning, during the ushering in of democracy in 1994, it would most likely have owned the reformation process and helped to spearhead and speed up policy development.

Hence, Tsatsire, Taylor and Raga (2010:273) maintain that local government cannot fulfil its mandate without a partnership with provincial and national government. The establishment and maintenance of sound intergovernmental relations have, therefore, become vital in ensuring the success of local government. It is for this reason that the rendering of services has to take place within the spirit of cooperative government, as 
Exploring Challenges of Municipal Service Delivery in South Africa (1994 - 2013) 93

stated in Chapter 3 of the Constitution of the Republic of South Africa, 1996, and all three spheres of government must be seen as equal partners rather than hierarchies, which seem to compete and overlook the importance of each other.

Considering the achievements of the past three terms of democratic government, it appears that the ANC-led government was doing too many things at once. For example, since 1994, South Africa has been involved in policy development, ceaselessly striving to address the injustices of the past, meeting the basic needs for all, reducing its physical infrastructure backlogs, establishing social security as well as implementing policy alleviation measures, amongst others (Hologram 2003:156). During the first democratic era, 1994 to 1999, the government aimed mainly at developing policies and transforming the state, but there were also parallel processes to be maintained in order to deliver municipal services through transitional local councils. Between 1998 and 2009 local government underwent yet another transformation while municipal service delivery was at stake; this is to say that such transformation accounted for the tardy development of service delivery in the municipalities.

Taken from President Mbeki's term, President Jacob Zuma's administration (i.e., from 2009 and due to end in 2014) has been obliged to focus solely on addressing municipal service delivery challenges. Hence, Kondlo (2010:8) claims that this administration is perceived by the masses as the public "service delivery administration" which came to power on the back of promises to the poor majority to provide a better future for all. However, inadequate service delivery is an escalating problem and a growing challenge confronting the current leadership; hence, Gumede asserts in Reddy (2010:81) that, for most township residents, getting a pavement fixed or the rubbish cleared that has piled up on the streets is a distant dream. To Gumede, many communities still do not receive water, electricity, housing and sanitation.

As Kanyane (2010:77) puts it, protests, strikes and riots within the first 100 days of Zuma's leadership showed the impatience of the citizenry. This impatience continues to frustrate the efforts of the new government to act responsibly. It is now obvious that President Jacob Zuma's first term of office, which is nearing to an end in 2014, still leaves communities disgruntled about service delivery. In this respect, Reddy (2010:81) is of the view that recurring protests against poor service delivery in all nine provinces is 


\section{Africa's Public Service Delivery and Performance Review}

cause for concern. Reminiscing about the historical past, the local sphere of government has been continually challenged to deliver quality services. Since 1998, the local sphere of government has not had enough capacity; hence Reddy's (2010:81) claim that there has, of late, been concern as to whether local government is in fact able to discharge its developmental mandate. According to Reddy (2010:81), the government launched Project Consolidate in 2004 to assist municipalities that were experiencing difficulties in undertaking their basic functions. The project identified 136 municipalities in need of assistance; 50 per cent of these municipalities were dysfunctional and were experiencing problems financially, in relation to service delivery or development tasks. The Local Government Expenditure Review (2011:4) warns that there is an urgent need to stabilise the senior management cadre of municipalities; in this sense, the appropriate technical skills need to be in place.

In 2000, the transition of municipalities into fully-fledged municipal status brought about a reduction from 843 transitional municipalities to a total of 284 municipalities (Sibanda 2012:2). The total number of municipalities was further reduced to 283, in 2006, following the demarcation process in terms of the Municipal Demarcation Act, 1998 (Act No. 27 of 1998), and constitutes 6 metropolitan municipalities, 231 local municipalities, and 46 district municipalities (Davids 2006, 1-10 and Reddy 2010,67). The cut was made again from 283 to 278 after the May 2011 local government elections (Sibanda 2012:2). At this point, the fully-fledged municipalities were expected to deliver effective and efficient services, but ward councillors and municipal councils were not ready to meet this obligation due to party political laxities. This led Gumede in Reddy (2010:81, 810), to believe that local politicians are rarely the kind that inspire confidence; they are more likely the political equivalent of a second-hand car salesman. In fact, local government appears to be the dumping place for those of mediocre talent who missed more gravylined political posts elsewhere. The cadres of political leadership in local government should have the institutional memory and technical expertise regarding how to run the affairs of the municipalities. The lack of these vital elements is a recipe for disaster which compromises the delivery of basic services by the municipalities to their respective communities.

Moreover, it is appropriate to underscore the fact that the municipal elections do not take place simultaneously with national and provincial elections. For example, the latest national and provincial elections took place on 22 April 2009, yet the municipal elections 
Exploring Challenges of Municipal Service Delivery in South Africa (1994 - 2013) 95

were conducted a year later, on 18 May 2011. This misalignment in elections has the potential to cause service delivery disruptions due to the appointment of a new suite of municipal mayors and councillors, to say the least, and calls for parallel tenure of office and strategic planning. There is therefore urgent need to conclude the protracted debate over a single public service and to integrate and harmonise the existing public service structures of both the national and provincial spheres of government with that of the local sphere of government. One may infer that unless budgeting and planning are integrated and municipal elections are planned and organised simultaneously with the national and provincial elections, as a coherent and integrated public service, planning and policy action will remain a disjuncture.

Following this array of logical arguments on municipal evolution, it is now appropriate to turn to technical resource capacity issues in underscoring the technical challenges confronting local government.

\section{Technical resource capacity}

In this section, technical resource capacity issues are unpacked to underscore the importance of adequately resourcing municipalities with the critical and technical skills required to efficiently and effectively deliver services in an attempt to fulfil the socioeconomic aspirations of the community. Section 53 of the Constitution of the Republic of South Africa, 1996, states that:

...a municipality must structure and manage its administration, budgeting and planning processes to give priority to the basic needs of the community, and to promote the social and economic development of the community, and participate in national and provincial development programmes.

IDASA (2010:1) emphasises that the fundamental goal of a democratic system is citizen satisfaction. The effectiveness of good local governance therefore needs to be judged by the capacity of local government structures to provide an integrated developmental approach to social and economic development issues and to supply essential services which are congruent with the needs and desires of the local 


\section{Africa's Public Service Delivery and Performance Review}

communities. In this regard, municipalities should be able to identify and prioritise local needs, determine adequate levels of services and allocate the necessary resources in order to fulfil the aspirations of the society.

According to Wallis and Dollery (2001:247), state incapacity in many developing countries is so endemic as to preclude even the adequate delivery of minimal services, let alone any more complex operations. South Africa is not immune to this problem. The rendering of municipal services to satisfy a specific community's needs is, of necessity, dependent upon the availability of sufficient resources. All spheres of government are frequently confronted with increasing and competitive demands for more and effective services and a general lack of sufficient resources to meet such demands; hence, Powell's (2012:16) view that the new sphere of government was being asked to do more with less resources and a crumbling skills base. As previously stated, the introduction of the Project Consolidate during President Mbeki's era attempted to resolve this crumbling skills base by deploying the necessary expertise to all affected municipalities. Powell (2012:18) confirms that Project consolidate deployed technical experts to 136 municipalities, generally in rural areas or former homelands which had the highest backlogs in basic services and were economically depressed. Similar programmes, such as Syenza Manje, were also employed; it was however difficult to measure the impact of these interventions.

The 2010 budget deficit is a case in point where the poor are vulnerable to the unintended consequences of policy decisions. According to the Local Government Budgets and Expenditure Review (2011: 62), municipalities' actual total operating expenditure increased in real terms by 11.8 per cent annually from 2006/07 to 2009/10 and is estimated to grow by 6.4 per cent over the medium term. More often than not, there exists a disjuncture between municipal expenditure and service delivery outcomes due to the inefficiencies in the machinery of government, and municipalities' consequent inability to deliver basic services to the community. Inefficiencies in service delivery or corruption might also quickly translate into increased expenditures and thus reduce the availability of resources to address the core objectives of poverty reduction and economic development (Local Government Budgets and Expenditure Review 2011:68). Hence, the reality on the ground is that increasing expenditure is incommensurate with policy outputs and this political and economic problem is a cause for concern. For example, there has been constant growth in capital expenditure on water and sanitation, 
Exploring Challenges of Municipal Service Delivery in South Africa (1994 - 2013) 97

however, the Blue Drop Report and Green Drop Report - by the Department of Water Affairs - indicate that there are a large number of smaller municipalities that have inadequate water and sanitation infrastructures, or which are in a very poor state (Local Government Budgets and Expenditure Review 2011:66).

It is a fact that municipalities depend on strong revenue bases to sustain their viability and ability to deliver services to individual households. In situations where these revenue sources are depleted, communities will likely be characterised by high levels of abject poverty and unemployment and also have strong elements of rural and informal economies, resulting in increasing demands for subsidisation and welfare, which are unsustainable. This is evidenced by the escalation of informal settlements which puts pressure on the municipalities to provide free basic services (FBS) such as water, electricity and housing for the indigents. A free basic service in itself is burdensome and causes policy failure (Fourie and Valeta 2008:39). These FBS, especially social grants, have the potential to put South Africa at risk of turning itself into a dependent society.

The inhibiting factor which influences the nature and scope of municipal services is the limited ability of citizens to pay for services, not discounting the intrinsic culture of non-payment for services. This, according to Reddy (2010:82), must be solved by the executive leadership of the municipality as the Masakhane campaign has made no difference over the past few years. It is therefore necessary that a baseline study should be conducted to survey the resource capacities in terms of basic service delivery of the municipalities. The data obtained should be compared to and measured against the expectations and demands of the citizens. The financial model of integrated and coherent public service to be proposed must, in the end, justify the means, including its contribution to the promotion of the general standard and welfare of society. It can be deduced that the government cannot afford to take policy decisions arbitrarily because such decisions always have financial implications which, in the end, irk the grassroots. Any change in the nature and scope of the municipal services rendered stems from a change in or amendment to policy and may become a financial burden if not carefully contemplated. 


\section{Africa's Public Service Delivery and Performance Review}

To this end, one of the serious challenges facing municipalities is how to deal with the ANC's policy of cadre deployment and the consequences of this policy. One inference which can be drawn is that:

The ANC's Cadre deployment systematically places loyalty ahead of merit and even of competence and is therefore a serious obstacle to an efficient municipal service. Politically connected, and in many cases, incompetent people are deployed in senior positions. Unqualified people are unable to deliver services efficiently and effectively (Centre for Development and Enterprise 2009:8-24).

While not all inefficiency problems can be blamed on the ANC's policy of cadre deployment, already, the ANC (2012:4) in its Fourth Policy Conference Recommendations acknowledged the setbacks related to cadre deployment and recommended that cadre deployment be underpinned by a rigorous system of monitoring and evaluation of the performance of those cadres deployed and elected to leadership positions. This includes the proposal that cadre deployment should also consider academic qualifications, making sure that loyalty is not considered ahead of but together with skills, competency and merit.

Nleya (2011:11) writes that service delivery remains a central, real and symbolic part of the actualisation of a meaningful life in poor areas. This is because improved services are linked to increasing the dignity of the poor who were systematically denied legitimate space and decent living conditions under the apartheid government. For this to be made possible, Tewary (2011:20-22) reasons that political will and leadership are needed to steer government structures responsible for service delivery, and these include stable municipal administration, in order to utilise public funds appropriately to achieve its intended goals.

Having discussed the technical resource capacity in context, it is befitting to look at key municipal service delivery challenges in the next section.

\section{Key municipal service delivery challenges}

It is apparent that the state continues to face difficulties in the delivery of basic municipal services even after 19 years of democracy. According to IDASA (2010:8), the 
Exploring Challenges of Municipal Service Delivery in South Africa (1994 - 2013) 99

failure of municipalities to deliver basic services not only causes immense hardship for the residents of municipalities, but can have a detrimental impact on social and economic development. Madue (2008:200) points out that the difficulties cannot be completely detached from the contextual realities in which the government functions. One of the major challenges is the incapacity of municipalities to deliver services to the communities. Dzengwa (2007:272) asserts that some municipalities still find themselves neither financially viable nor economically active. In such instances, these municipalities are under distress and have been constrained in their ability to provide services and to sustainably generate their own revenues.

Of further importance are service delivery protests which are common strategies (either good or bad) to express dissatisfaction with the state. The number of protest activities in various parts of South Africa suggests a substantive level of impatience and dissatisfaction as already alluded to earlier in this discussion. In spite of South Africa being accepted by the world as a democracy with a good constitution, democratic elections and parliamentary oversight, there are many instances of deplorable and slow paced service delivery which, according to Reddy (2010:79), compels local communities to engage in protest action to vent their frustrations, especially during the run up to elections. According to Ndletyana (2007:101), the deplorable state of service delivery is due to the fact that municipalities throughout the country are generally in a less than satisfactory situation.

Cooperative Governance and Traditional Affairs (2009:12) clearly states that councillors have been accused of being arrogant and insensitive to the needs of the community. Lack of effective conflict management and the absence of coherent systems to measure service delivery, or the quality of the client interface, are some of the political reasons underlying protest action. Increasing service delivery protests and campaigns about escalating rates suggest perceptions of poor governance and lack of capacity at municipal level. The State of the Cities Report (2011:120) refers to governance as the activity of governing and government, the instrument that undertakes it; there is a need to strengthen accountability mechanisms [and community engagement] to ensure effective and efficient service delivery that is free from conflicts, protests and riots. 
100 Africa's Public Service Delivery and Performance Review

Mbaku (2008:427-436) asserts that in several regions around the world, especially in Africa, corruption remains an important obstacle to political and economic development. While corruption enriches only a few government officials, politicians and 'tenderpreneurs' for example, it has generally stunted the creation of wealth and severely limited and hampered the government's ability to deal effectively with poverty and deprivation. Daw (2006:57) writes that in recent years, many municipal distribution portals suffered financial collapse and many others are facing severe problems with debt, including their inability to pay the state-owned energy supplier. Mashigo (2010:128) contends that the electricity crisis in 2007 impacted upon South Africa's economic growth and led to a decline in foreign investor confidence. The crisis has negatively affected productivity; for example, it continues to hinder farmers from harvesting their crops, forces producers to partially close mines, putting the very jobs at risk that should be nurtured, and it prevents new building projects from being electrified, thus causing members of the society to struggle to access municipal energy services (Mashigo 2010:128). The continuing unpredictability of the power supply has the potential to cause major municipal service delivery disruptions.

It is of paramount importance to state upfront that stakeholders are critical in service delivery, but sometimes handling huge projects which involve a multiplicity of stakeholders can lead to the collapse of municipal services. The delivery of municipal services is not simply an administrative or managerial problem, but a convoluted political process of deciding who gets what, when, how, where and from whom because of the many actors that operate on multiple levels. For example, in deciding upon a municipal infrastructure project, it includes many players such as a ward councillor and ward committee to identify the need for such a road or a bridge in consultation with the community; a municipal mayor and council to endorse such a lifeline project linked to Integrated Development Planning (IDP); various levels of the senior municipal management to plan and budget for such a project and service providers to be contracted through the supply chain process in order to implement the project and to ensure tangible deliverable outcomes within the specified contracted period. This appears simple, but it is complex as it involves many players such as members of the political, managerial, civil and business communities, amongst others, at different phases of service delivery. 
Exploring Challenges of Municipal Service Delivery in South Africa (1994 - 2013) 101

Another issue affecting municipal service is planning. The national, provincial and local spheres of government planning are not aligned and coordinated; this usually results in the duplication and wastage of resources (Fourie and Valeta 2008:139). For example, many Local Economic Development (LED) and IDP initiatives are not aligned with provincial and national priorities. Fourie and Valeta (2008:139-140) warn that if the problem of service delivery remains unresolved for much longer, the country will continue to struggle to bridge the gap of inequality between the rich and the poor. Metaphorically, the "haves" (who are in the minority) are trapped within (among) the sea of the "have-nots" (who are in the majority) and this gap remains unbridged.

Bosch (2011) adds that planning in South African government has not yet taken into account the reality of different cycles because Monitoring and Evaluation (M\&E) is not yet the life-blood of sound and efficient planning and implementation. Whist there is some level of good planning cycle in government, effective M\&E still has to play a major role in enhancing the effectiveness of development programmes and projects. This planning cycle according Bosch (2011) should focus on the results that matter in order to learn from past successes and challenges so that current and future initiatives are better able to expand people's choices and also to improve their lives.

In the first five years of the new democratic government in South Africa, very few departments engaged in any systematic monitoring and evaluation of their policies and programs. The late 1990s saw early attempts by government to introduce Governmentwide Monitoring and Evaluation (GWM\&E). These attempts were not successful and in 2004 there was a renewed effort at GWM\&E. The policy framework for the GWM\&E system was approved in 2007 and provides much needed clarity about the scope and purpose of the GWM\&E System (Bosch, 2011). Hence, the Policy Framework for the GWM\&E system (2007:5) outlines that the government is also in the process of refining its system of monitoring and evaluation to improve organisational performance and the quality of outputs, providing an early-warning system and implementation strategies to respond speedily to problems as and when they arise.

The establishment of the Ministry for Performance Monitoring and Evaluation in January 2010 in the Presidency following the 2009 general elections has catapulted GWM\&E to greater prominence. The National Planning Commission was also 
established in 2009. This was based on the premise that getting development results depend on much more than good financial management. Government agreed that for any organization, public or private, delivery depends on the quality not only of the financial side of its balance sheet, but also of its real side-the quality of its people, and how effectively they are deployed and led. Hence a paradigm shift from traditional M\&E focus to results/outcomes based approach (Bosch:2011). In this respect, Licona (2007:6) states that monitoring and evaluation systems must generate reliable and timely technical data to enable informed decisions to be made. One observes that as evaluation accounts for what has happened, monitoring gives an account of what should happen so as to allow room for early warnings and intervention to take its course. However, despite the establishment of the Department of Performance Monitoring and Evaluation (DPME) during Zuma Administration, GWM\&E remains a challenge as it is not yet practically institutionalised and co-ordinated. DPME is still in a learning phase to make the GWM\&E evolution and revolution practically impactful, especially at local sphere of government where it matters most.

Phillips (2012:15) admits that a lot of grounds still need to be covered in institutionalising the concept of monitoring and evaluation in government. For example, Bosch (2011) says that developing monitoring and evaluation capacity in government is an on-going challenge that would still persist for some time unless more creative solutions are introduced. The number of technically proficient GWM\&E practitioners in government is still not sufficient to meet the increasing demand for GWM\&E. The problem is more acute in provincial and local governments. There are still challenges in the GWM\&E system that need attention such as creating a demand for and better understanding of GWM\&E in government. One also observes that evaluation is buried under monitoring; hence CLEAR (2012:17) warns that evaluation should be elevated from under the shadow of monitoring.

To this end, in spite of the achievements attained since 1994, there are still contradictions in service delivery and many challenges for socio-economic development, especially in rurally based municipalities. These include, according to Hologram in Kanyane (2010:87), high levels of poverty in and around urban areas, but mostly affecting rural towns. Hologram, in Kanyane, goes further to say that despite South Africa's relative wealth and a developing modern economy, economic growth has not yet benefitted the majority of the country's poor communities. To Hologram, South Africa 
Exploring Challenges of Municipal Service Delivery in South Africa (1994 - 2013) 103

remains one of the most socially unequal countries in the world. It appears that, since 1994, economic growth has been associated with growing poverty and increasing exclusion of the poor from the mainstream of the market economy (Hologram in Kanyane 2010:87).

Having raised crucial service delivery challenges, it is now befitting to suggest possible propositions to attempt to improve delivery of services in response to fulfilling developmental local government agenda hence the next section.

\section{Some possible propositions for consideration}

To this end, it is crucial to recognise that the article formulates a basis from which to deduce that municipal service delivery remains a challenge even during the 20 years of democratic rule by the ruling party. The Zuma administration was seen as the beacon of hope for a change in the situation, but this requires a complete overhaul even beyond his current term of office which is characterised by community protests, poor municipal service delivery in selected municipalities, rampant corruption especially in supply chain, municipal audit queries and undue party political influence, to mention a few of its challenges. Powell (2012:24) states that improving the quality of municipal administration is a key priority and will require: firstly, those competent professionals are appointed to senior management positions and; secondly, that municipal administration is insulated from undue party political influence and pressures. It is against this background that the following propositions are made in response to critical issues raised:

Firstly, as it came to the attention of this article that most municipalities are not financially viable and economically active, hence they are under distress and have been constrained in their ability to provide services and to sustainably generate their own revenues. Given this challenge, it is proposed that municipalities should improve their revenue enhancement and debt management model to broaden their revenue base without being heavily dependent on the National Treasury (NT) equity shares and cash injection bailouts. Broadening the revenue base and also managing debt dynamics mean to also deliver more quality services equitably to the communities. Revenue collection must be commensurate with the service delivered to stimulate the community's culture of payment to avoid consumer debts which are burdensome. de Wet (2004:8) states that 
it is up to all municipalities to ensure that they do everything in their power to enhance their revenue earning capabilities as well as their revenue collection processes. According to Kanyane (2011:944), municipalities should not only introduce indigenous and credit control policies, but should also develop revenue enhancement strategies to implement those policies without fail. Municipalities in distress should draw lessons and best practices from the well performing municipalities. The point made here is that until such municipalities are able to viably raise their own revenues and that grants and equity shares drawn from the NT are well understood as complementary stimuli package, service delivery will always remain a challenge.

Secondly, when coming to service delivery protests, they have cause and effect relationship. The effects of service delivery protests are more damaging hence the need to understand the causes of such protests is crucial before attempting to resolve them. One of the causes of these protests is simply a collapse of communication between the municipalities and the communities. It is therefore critical to propose that public participation or rather community engagement should be strengthened. Community engagement should be a two-way process, and not a one way tick-in-the-box exercise by the municipalities just to comply with public participation policies. It is not about taking a stock of how many community meetings were held, but should be about active participation of those communities in every stage of the policy cycle to robustly engage and resolve municipal challenges as a collective. This should be coupled with effective monitoring and evaluation that is integrated and coherent cutting across three spheres of government.

Thirdly, as service delivery is not only an administrative process, but also convoluted political process, one proposes that the interface between the municipal council and the executive as well as the council and the community must not be left to chance to avoid municipal mayors and councillors encroaching in the administrative affairs of the municipalities. Municipal managers must manage, but should be held accountable by the mayor or the council. There are in-built accountability mechanisms drawn from Local Government: Municipal Structures Amendment Act, 2003 (Act No. 1 of 2003) which must be respected by both politicians and municipal officials as the latter can also frustrate the former.

Fourthly, respect of accountability chain includes councillors whom according to earlier discussion, have been accused of being arrogant and insensitive to the needs of 
Exploring Challenges of Municipal Service Delivery in South Africa (1994 - 2013) 105

the community. It is for this reason that Paradza, Mokwena and Richards (2010:89) propose that residents' trust in the ability of local government to deliver services needs to be restored via a number of measures, including regular assessment of councillor performance undertaken in a systematic and transparent way and based on set of norms and standard of indicators applied across all municipalities.

Fifthly, having discussed earlier that corruption remains an important obstacle to political and economic development, municipalities are not immune from this malaise. It is therefore recommended that municipalities should be equipped with ethics integrity architecture. This includes tightening Municipal Public Accounts Committees (MPACs) (Sec 79 of the Municipal Structures Act); Audit Committee (Sec 166 of the MFMA), Supply Chain Management (SCM) (Chapter 11 of MFMA) and other council committees (Sec 79 of the Municipal Structures Act). It is for this reason that Municipal Council oversight must be enhanced and stepped up by introducing zero tolerance against corruption in all spheres of government. The recent Anti-Corruption Bureau (ACB) for example introduced by the current Minister of Public Service and Administration (DPSA) is welcomed and should work closely with other law enforcement and corruption busting agencies of government such as the Special Investigation Unit (SIU), Asset Forfeiture (AF), Financial Investigation Unit (FIU) and the newly established Office of the Chief Procurement Office (CPO) in the National Treasury (Sisulu, 2013), but this bureau should also cascade in the municipalities to stop the rot by barring, blacklisting and prosecuting corrupt municipal officials, syndicates and service providers.

Lastly, but not the least, the issue of planning was raised as a service delivery challenge and cannot be overemphasised; more so, the national, provincial and local planning are not integrated including in some situation the IDPs and LEDs. On this basis, the next phase of planning at IDPs and LEDs levels should now reflect broader planning and this should be informed by provincial and five national government priorities (creation of decent work and sustainable livelihoods, education, health, rural development, food security and land reform and the fight against crime and corruption), Millennium Development Goals (MDGS) as well as Industrial Policy Action Plan (IPAP) and National Growth Path (NGP). The bottom up and top down approach must interface as both three spheres of government are seen by the communities as equal partners in 
service delivery or more importantly, in pursuing the developmental agenda of local government.

Same can be said to evolution and revolution of GWM\&E which must be deepened and integrated across and within the three spheres of governments, including districts and local municipalities. Currently, as the GWM\&E is a tool crucial for maintaining checks and balances in service delivery, Bosch (2011) proposes that it should provide the analysis and practical evidence to effect the trade-offs between various alternative strategies. It is for this reason that the GWM\&E could be effective if the way of doing things in government is turned around into modern culture of business unusual, of course, this will take time, but it is a step in the right direction. Mackay (2006:8) writes that monitoring and evaluation should identify deplorable situations and consequently provide insights into how to intervene while the work is in progress. The information gathered should be translated into analytical, action-oriented reports that facilitate effective integrated planning, policy making and intervention to attempt to resolve the service delivery challenges already discussed.

\section{Conclusion}

To this end, this article has succeeded in exploring municipal service delivery through municipal evolution and technical capacity lenses, including key challenges. Thus, it raised critical issues for consideration. Firstly, this article has argued that service delivery problems and challenges are a direct consequence or manifestation of weak governance, municipal capacity constraints and poor planning amongst others. Secondly, it has also demonstrated that the need for strong governance and technical skill capacity is essential to improve municipal service delivery. Lastly, the article has also argued that the prime objective of resolving municipal service delivery challenges is to place greater emphasis on professional expertise free from party politics as well as to effectively monitor and evaluate service delivery in order to leave nothing to chance. 
Exploring Challenges of Municipal Service Delivery in South Africa (1994 - 2013) 107

\section{List of References}

- ANC. 2012. Recommendations from the $4^{\text {th }}$ National Policy Conference, ANC Policy Conference, pp. 1-54.

- Bosch, L. 2011. The evolution of monitoring \& Evaluation in South Africa, http://copmfdrafrica.ning.com/profiles/blogs/the-evolution-of-monitoring-ampevaluation-in-south-africa, Accessed on 26 August 2013.

- Centre for Development and Enterprise. 2009. South Africa's public service: Learning from success. CDE Round Table Occasional Paper, no. 13, pp. 1-28.

- CLEAR. 2012. African Monitoring and Evaluation System, exploratory case studies, Centre for Learning on Evaluation and Results (CLEAR), Wits, Johannesburg, South Africa

- Cooperative Governance and Traditional Affairs. 2009. State of local government in South Africa, Overview Report of National State of Local Government Assessments, Ministry of Cooperative Governance and Traditional Affairs, South Africa.

- Davids, I. 2006. Learning about local government: $A$ first step towards active engagement. Cape Town: Foundation for Contemporary Research (FCR).

- Daw, O.D. 2006. Restructuring and reform in the electricity industry in South Africa towards competition of state-owned utility. Journal of Public Administration. Spring Conference proceedings, pp. 52-65.

- de Wet, W. 2004. Revenue Enhancement in Local Government, IMFO, 5, no.3, pp. 8-10.

- Du Plessis, L.M. 2009. New political leadership in South Africa: Implications for sustainable local governance, Working Group IV, IASIA Conference, Rio de Janerio, Brazil.

- Dzengwa, S. 2007. Perspectives on donor aid: Quo Vadis South African Local Government. Journal of Public Administration, vol 42, no 3, pp. 271-283.

- Fourie, D. and Valeta, L. 2008. Intergovernmental fiscal relations in the South African context. Journal of Public Administration, vo.2, no 1, pp. 31-141. 
108 Africa's Public Service Delivery and Performance Review

- Hologram.2003. Issues and practice in South African local government. Cape Town: Nolwazi Publishers

- IDASA. 2010. The state of local government and service delivery in South Africa: Issues, challenges and solutions. Submitted to the Portfolio Committee on Cooperative Governance and Traditional Affairs (COGTA) for Public Hearings: Coordinated Service Delivery, IDASA Local Government Unit (LGU).

- Kanyane, M.H. 2010. Service delivery in question in Kondlo, K. and Maserumule, M.H. 2010. The Zuma Administration: Critical Challenges. Cape Town: HSRC Press.

- Kanyane, M.H. 2011. Financial viability of rural municipalities in South Africa, Journal of Public Administration, vol 46, no 2, pp. 935-945.

- Kondlo, K. 2010. Political and Governance Challenges in Kondlo, K. and Maserumule, M.H. 2010. The Zuma Administration: Critical Challenges. Cape Town: HSRC Press.

- Licona, G.H. 2007. Monitoring and evaluation system. Consejo Nacional de Evaluación de la Política de Desarrollo Social (CONEVAL), Mexico.

- Mackay, K. 2006. Institutionalization of monitoring and evaluation systems to improve public sector management. Evaluation Capacity Development Working Paper Series No 15. World Bank Independent Evaluation Group.

- Madue, S. 2008. Policy implementation in a turbulent environment. Journal of Public Administration, vol 43, no 3.1, pp. 197-206.

- Maserumule, M.H. 2010. Consolidating a developmental state agenda: a governance challenge in Kondlo, K. and Maserumule, M.H. 2010. The Zuma Administration: Critical Challenges. Cape Town: HSRC Press.

- Mashigo, P. 2010. Socio-economic development and poverty reduction in South Africa in Kondlo, K. and Maserumule, M.H. 2010. The Zuma Administration: Critical Challenges. Cape Town: HSRC Press.

- Mbaku, J.M. 2008. Corruption clean-ups in Africa: Lessons from public choice theory. Journal of Asian and African Studies, vol 43, no 4, pp. 427-456.

- Ndletyana, M. 2007. Municipal elections 2006: protests, independent candidates and crossborder municipalities in Buhlungu, S. Daniel, J. Southall, R. and Lutchman, J. (eds). 2007. Sate of the Nation. Cape Town: HSRC Press.

- Nleya, N. 2011. Linking service delivery and protest in South Africa: An exploration of evidence from Khayelitsha. Africanus, vol 1, no 1, pp. 3-13. 
Exploring Challenges of Municipal Service Delivery in South Africa (1994 - 2013) 109

- Paradza, G, Mokwena, L and Richards, R. 2010. Assessing the role of councillors in service delivery at local government level in South Africa, Centre for Policy Studies Research Report 125, pp. 1-94

- Phillips, S. 2012. The Presidency Outcome Based Monitoring and Evaluation: our Approach, Evolution of Monitoring and Evaluation in the South African Public Service, PSC News.

- Powell, D. 2012. Imperfect transition-local government reform in South Africa (199419912).Sun Media MeTro and authors, pp. 11-30

- Reddy, S. 2010. Democratic decentralisation and local democracy in South Africa reexamined quo vadis? Politeia 29(3), pp. 66-87

- Sangweni, S.S. 2003. Performance management as a leadership and management tool. The 2nd Senior Management Conference (SMS), $15^{\text {th }}$ to $17^{\text {th }}$ September, Port Elizabeth, South Africa.

- Sibanda, M.M. 2012. Monitoring customer-focused quality service delivery in Local government: conceptual issues and perspectives for consideration. Africa's Public Service Delivery and Performance Review Journal, vo 1, no 1, pp. 1-20.

- Sisulu, L.N. 2013. Anti-corruption bureau to fast track cases against public servants, SA News.gov.za http://www.sanews.gov.za/south-africa/anti-corruption-bureau-fast-trackcases-against-public-servants Accessed 2 February 2014

- State of the Cities Report. 2011. South African Cities Network. 2001-2010. Towards resilient cities: $A$ reflection on the first decade of a democratic and transformed local government in South Africa. State of the Cities Report, pp. 120-141.

- South Africa (Republic). 1996. Constitution of the Republic of South Africa, (Act 108 of 1996) as amended, Government Printers, Pretoria, South Africa.

- South Africa (Republic). 1998. Local Government: Municipal Demarcation Act (Act. No. 27 of 1998), Government Printers, Pretoria, South Africa.

- South Africa (Republic). 2003. Local Government: Municipal Finance Management Act, 2003 (Act No 56 of 2003), Government Printers, Pretoria, South Africa.

- South Africa (Republic). 2003. Local Government: Municipal Structures Amendment Act, 2003 (Act. No. 1 of 2003), Government Printers, Pretoria, South Africa. 


\section{Africa's Public Service Delivery and Performance Review}

- South Africa (Republic). 2007. Policy Framework for the GWM\&E System. Government Printers, Pretoria, South Africa.

- South Africa (Republic). 2009. Local Government: Municipal Property Rates Amendment Act, (Act No 9 of 2009), Government Printers, Pretoria, South Africa.

- $\quad$ South Africa (Republic). 2011. Local Government Budgets and Expenditure Review, 2006/72012/13 Cape Town: Somerset Printers, South Africa.South Africa (Republic). 2011. Local Government: Municipal Systems Amendment Act (Act. No 7 of 2011), Government Printers, Pretoria, South Africa.

- Tewary, S. 2011. The top five risks for the municipalities in South Africa, IMFO 11, no 4,.pp. 20-22.

- Tsatsire, I. Taylor, R.D and Raga, K. 2010. Local service delivery enhancement - attitudes: a case study of the Nelson Mandela Bay Municipality. Journal for Transdisciplinary Research in Southern Africa, vol 6, no1, pp. $271-286$.

- Wallis, J. and Dollery, B. 2001. Government failure, social capital and the appropriateness of the New Zealand model for public sector reform in developing countries. World Development, vol 29, no 2, pp. 245-263.

AUTHOR'S CONTACT:

KANYANE, Modimowabarwa

Human Science Research Council

South Africa

Email: hkanyane@hsrc.ac.za

\section{AFRICA'S PUBLIC SERVICE DELIVERY AND PERFORMANCE REVIEW

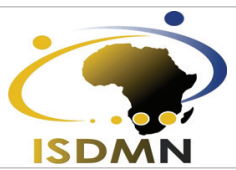

ISSN 2310-2195 (print) ISSN 2310-2152 (online) 